\title{
Peningkatan Nilai Tambah Ubi Jalar Putih Melalui Diversifikasi Olahan Makanan Menjadi Stik Ubi di Desa Renah Alai Kecamatan Jangkat Kabupaten Merangin
}

\author{
Hardiani $^{1 * *}$, Dwi Hastuti ${ }^{2}$, Zulfanetti $^{3}$, Erni Achmad ${ }^{4}$, Purwaka Hari Prihanto ${ }^{5}$ \\ 1,2,3,4,5) Fakultas Ekonomi dan Bisnis, Universitas Jambi, Jl. Raya Jambi - Muara Bulian KM. 15, \\ Muaro Jambi, Jambi
}

\begin{tabular}{l|l|l|l} 
Diterima: 18-07-2021 & Direvisi: 30-07-2021 & Disetujui: 31-07-2021 & Dipublikasi: 03-08-2021
\end{tabular}

\begin{abstract}
Renah Alai Village is very potential in agricultural cultivation, including white sweet potato cultivation. Currently, around $80 \%$ of the people of Renah Alai Village cultivate sweet potatoes to meet local food requirements. Even some of the sweet potato production is sold outside the village. The amount of sweet potato production is not followed by an increase in the added value of the sweet potato so that the selling value of a sweet potato is low. Therefore, the need for diversification of processed sweet potato foods is expected to increase the added value of sweet potatoes, such as making sweet potato sticks. The purpose of this community service activity is to provide knowledge and skills to the people of Renah Alai Village in processing sweet potatoes to increase the added value of sweet potatoes. This activity is focused on processing sweet potato sticks. The results of this service are expected to be an opportunity to increase the income and welfare of sweet potato farmers and prevent the decline in sweet potato prices when harvesting simultaneously.
\end{abstract}

Keywords: sweet potato, local food, added value, food diversification

\begin{abstract}
Abstrak
Desa Renah Alai sangat potensial dalam budidaya pertanian termasuk budidaya ubi jalar putih. Saat ini sekitar $80 \%$ masyarakat Desa Renah Alai membudidayakan ubi jalar dalam memenuhi pangan lokal. Bahkan sebagian produksi ubi jalar dijual keluar desa. Banyaknya produksi ubi jalar tidak diikuti dengan peningkatan nilai tambah dari ubi jalar tersebut sehingga nilai jual ubi jalar sangat rendah. Oleh karena itu, diperlukannya diversifikasi olahan makanan ubi jalar diharapkan mampu meningkatkan nilai tambah ubi jalar misalnya pembuatan stik ubi. Tujuan kegiatan pengabdian kepada masyarakat ini adalah untuk memberikan pengetahuan dan keterampilan kepada masyarakat Desa Renah Alai dalam pengolahan ubi jalar sehingga dapat meningkatkan nilai tambah ubi jalar. Kegiatan ini difokuskan kepada pengolahan stik ubi jalar. Hasil pengabdian ini diharapkan dapat menjadi peluang untuk meningkatkan pendapatan dan kesejahteraan petani ubi jalar serta mencegah turunnya harga ubi jalar ketika panen serempak.
\end{abstract}

Kata kunci: ubi jalar, pangan lokal, nilai tambah, diversifikasi makanan

\section{Pendahuluan}

Desa Renah Alai adalah salah satu desa yang ada di Kecamatan Jangkat Kabupaten Merangin. Desa ini dikenal dengan iklim yang sejuk dan segar karena. Desa Renah Alai merupakan daerah yang potensial sebagai penghasil bahan-bahan kebutuhan pokok karena lokasinya dekat dengan pegunungan lembah Masurai. (Parmadi, dkk., 2019) Selain itu, suasana yang alam yang asri, keramahan masyarakat dan potensi sumber daya alamnya yang

\footnotetext{
*Penulis korespondensi

Email: hardiani@unja.ac.id
} 
melimpah membuat banyak masyarakat baik dari Provinsi Jambi dan luar Provinsi Jambi, bahkan touris dari luar negeri yang tertarik untuk mengunjunginya.

Desa Renah Alai memiliki potensi agrowisata yang potensial, selama tetap dapat mempertahankan kebudayaan lokal untuk menjaga kelestarian lingkungan (Junaidi, dkk.2019). Selain itu, menurut Chrisnasari, dkk (2015) jika kondisi lingkungan tetap terjaga keasriannya akan dapat menjadikan desa tersebut sebagai desa tujuan wisata yang potensial. Pengembangan dalam peningkatan menjadi desa wisata secara umum bertujuan untuk meningkatkan kesejahteraan masyarakat (Zamzami \& Hastuti, 2019). Oleh karena itu, menurut Zulgani, dkk (2019) berbagai aspek dalam peningkatan desa wisata juga harus terpenuhi melalui konsep agro eco tourism yang bertujuan dalam membangun ekonomi suatu wilayah dengan mengedepankan pemanfaatan sumberdaya yang ada.

Salah satu jenis pertanian yang dikembangkan masyarakatnya adalah tanaman palawija. Saat ini, jenis budidaya tanaman palawija di Desa Renah Alai dan sudah dikembangkan setiap tahunnya adalah budidaya ubi jalar putih. Potensi pemanfaatan ubi jalar putih di Desa Renah Alai yang sangat besar. Sekitar 80 eprsen masyarakat Desa Renah Alai telah membudidayakan ubi jalar putih. Ubi jalar putih atau nama lainnya Ipomea Batatas Linneaus termasuk jenis tropikan dan subtropika. Selain pemanfatan daunnya sebagai sayuran, tanaman ubi jalar putih juga dapat dimanfaatkan umbinya. Saat ini ubi jalar putih telah digerakkan oleh pemerintah sebagai makanan pokok, subtitusi dan suplementasi karbohidrat (Zuraida \& Supriati, 2001).

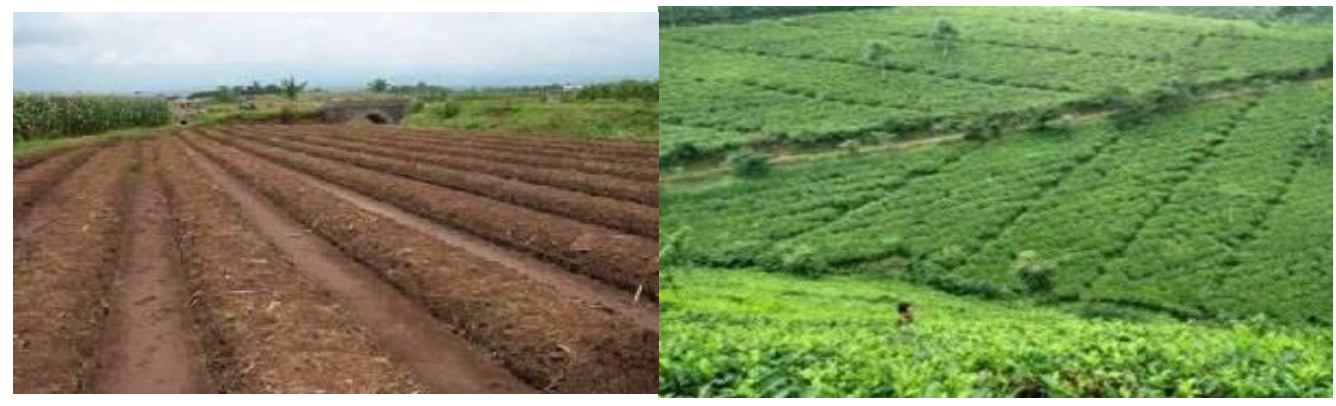

Gambar 1. Potensi Tanaman Ubi Jalar di Desa Renah Alai Kecamatan Jangkat

Sebenarnya sumber karbohidrat juga dapat dijumpai pada padi, ubi kayu dan jagung. Akan tetapi yang memiliki tingkat gula yang rendah salah satunya berada pada tanaman ubi jalar sehingga ubi jalar memiliki peluang yang besar jika dikembangkan untuk kedepannya. Menurut Septianti \& Fatah (2013) saat ini produktifitas ubi jalar Indonesia didorong oleh perkembangan agro industry melalui pengolahan produk dari mulai pasca panen sampai ke hasil-hasil produk turunannya. Adanya kenaikan nilai tambah ubi jalar akan meningkatkan pendapatan sekaligus kesejahteraan petani (Harnowo dkk., 1994).

Selama ini, produksi olahan ubi jalar masih sangat sedikit di Desa Renah Alai. Sebagian besar masyarakat desa langsung menjual hasil panen ubi jalar kapada pengepul dan pedagang di pasar Kabupaten Merangin dan kota lainnya. Kondisi ini menyebabkan harga ubi jalar cenderung rendah dan berfluktuasi.

Sedikitnya produksi olahan ubi jalar di Desa Renah Alai karena masih minimnya pengetahuan masyarakat tentang olahan-olahan yang dapat dihasilkan dari tanaman ubi jalar misalnya keripik, stik, brownies, tepung, mie. Oleh karenanya, kegiatan pengabdian masyarakat ini bertujuan untuk meningkatkan pengetahuan dan keterampilan masyarakat dalam pengolahan tanaman ubi jalar yang salah satu bentuknya adalah stik ubi jalar.

\section{Metode}

Kegiatan pengabdian kepada masyarakat memiliki beberapa tahapan yang dilakukan. Pada tahap pertama ini, tim pengabdian melakukan beberapa kegiatan yaitu 1) Persiapan tim 
pengabdian, 2) Survei lokasi pengabdian, 3) Penetapan Lokasi Pengabdian, 4) Penetapan mahasiswa yang terlibat.

Pelaksanaan kegiatan dilakukan dengan beberapa metode. Pertama: Focus Group Discussion (FGD) untuk memahami berbagai kendala yang dihadapi masyarakat dalam pengolahan ubi jalar. Kedua, pendampingan praktik pengolahan ubi jalar menjadi produk stik ubi jalar. Ketiga, pembelajaran konsep-konsep pengembangan usaha yang baik.

Tahap selanjutnya adalah tahap reviews dan evaluasi untuk mengevaluasi program yang telah dilaksanakan, kendala-kendala yang ada di lapangan, serta cara solusi penangannya sehingga program pengabdian kepada masyarakat dapat tepat sasaran, efektif dan maksimal

\section{Hasil dan Pembahasan}

Berdasarkan potensi iklim, dan jenis tanah yang dimiliki oleh masyarakat di Desa Renah Alai Kecamatan Jangkat maka produksi ubi jalar akan tumbuh baik dan optimal sehingga hasil panen ubi jalar juga akan semakin meningkat. Sayangnya peningkatan produksi tanaman ubi jalar tidak sejalan dengan peningkatan output yang dihasilkan, atau dengan kata lain banyak hasil panen ubi jalar langsung dijual ke tengkulak dengan harga yang relatif lebih murah. Seringkali petani merugi karena harga jual ubi jalar yang lebih rendah dibandingkan dengan ongkos produksi tanaman ubi jalar.

Umumnya permasalahan terkait dengan sifat tanaman ubi jalar putih dengan umur simpan yang relative pendek yaitu hanya bertahan 10 hari. Jika disimpan terlalu lama akan muncul poyo, tumbuh tunas dan berat ubi yang menyusut. Umur simpan yang relatif pendek menyebabkan harga jual ubi jalar sangat murah. Selain itu musim panen yang bersamaan menyebabkan penawaran ubi jalar yang melimpah sedangkan permintaan relatif sedikit sehingga harga ubi jalar akan turun atau anjlok.

Berdasarkan hal tersebut, perlu dilakukan diversifikasi produk olahan ubi jalar. Namun demikian, saat ini produksi olahan ubi jalar ini masih relatif sedikit di Desa Renah Alai. Rendahnya pemanfaatan tanaman ubi jalar disebabkan oleh keterbatasan pengetahuan atau kurangnya pengetahuan dan keterbatasan teknologi. Hal ini menjadi permasalahan yang harus diselesaikan secara cepat, salah satunya dengan upaya pengelolahan ubi jalar putih menjadi stik ubi jalar.

Kegiatan pelaksanaan pengabdian kepada masyarakat di Desa Renah Alai ini diawali dengan koordinasi dengan Pemerintah Desa Renah Alai. Berdasarkan hasil koordinasi tersebut disepakati tempat dan waktu kegiatan serta peserta sasaran. Hasil koordinasi tersebut dilanjutkan dengan Focus Group Discussion (FGD) untuk menghimpun aspirasi masyarakat, kendala-kendala yang dihadapi dalam pengolahan ubi jalar dan harapan ke depan dalam upaya peningkatan kesejahteraan mereka.

Selanjutnya dilakukan pelatihan dan pendampingan pembuatan stik ubi jalar. Peserta pelatihan dan pendampingan adalah generasi muda, ibu-ibu, bapak-bapak yang ada di Desa Renah Alai yang pekerjaannya mayoritas pekerjaannya adalah petani.

Setelah mendapatkan keterampilan pengolahan ubi jalar menjadi stik ubi jalar, peserta dibekali dengan pengetahuan manajemen usaha yang baik. Hal ini ditujukan, agar produk yang dihasilkan masyarakat dapat berkelanjutan dan menjadi usaha yang dapat meningkatkan kesejahteran masyarakat.

Reviews dan evaluasi ini dilakukan di akhir kegiatan. Review dan evaluasi dilaksanakan dalam bentuk diskusi dan tanya jawab serta mendengarkan berbagai permasalahan atau masukan dari peserta.

Berdasarkan hasil review dan evaluasi tersebut didapatkan gambaran bahwa masyarakat merasa optimis pengolahan ubi jalar menjadi menjadi stik ubi jalar dapat menjadi salah satu upaya dalam pemberdayaan petani dan masyarakat di Desa Renah Alai. Stik ubi jalar ini dapat menjadi makanan khas Desa Renah Alai dan dan menjadi salah satu 
pendukung daya tarik wisata ke daerah ini. Pengolahan ubi jalar menjadi stik ubi jalar ini juga akan dapat mengatasi penurunan harga ubi jalar ketika terjadi panen serempak..

\section{Kesimpulan}

\section{Kesimpulan dan Saran}

Kegiatan pengabdian memberikan gambaran terkait dengan pemanfaatan ubi jalar yang tidak hanya di rebus dan dijual mentah saja, tetapi juga diolah menjadi stik ubi untuk mendapatkan keuntungan yang lebih besar bagi petani dan masyarakat di Desa Renah Alai. Stik Ubi ini juga dapat menjadi oleh-oleh khas dari Desa Renah Alai untuk wisatawan.

\section{Saran}

Perlunya bimbingan dari Dinas Perindustrian dan Perdagangan terkait pengembangan usaha stik ubi agar dapat menjangkau pangsa pasar yang potensial. Selain itu perlu kerjasama dengan Dinas Pariwisata sehingga dapat bersinergi dalam mempromosikan hasil olahan usaha masyarakat Renah Alai selain dari potensi pertanian dan pariwisatanya

\section{Ucapan Terima Kasih}

Penulis mengucapkan terima kasih kepada Universitas Jambi yang dalam hal in telah memberi bantuan pendanaan dan dukungan moral sehingga kegiatan pengabdian pada masyarakat ini dapat terlaksana dengan baik dan lancar. .

\section{Daftar Pustaka}

Chrisnasari, R., Soesanti, A., \& Askitosari, T.D. (2015). Pengembangan Bisnis Berbasis Ubi Jalar pada Masyarakat Desa Tamiajeng-Trawas, Kabupaten Mojokerto. [Makalah] Join Conference on Comdev 2015, 10 - 11 September 2015, Surabaya.

Harwono, D., Antarlina, S.S, \& Mahagyosuko, H. (1994). Pengelolahan Ubi Jalar guna mendukung diversifikasi pangan dan agroindustry. [Makalah] Seminar Penerapan Teknologi Produksi dan Pasca Panen Ubi Jalar Mendukung Agro Industri, Balilitian, Malang, 145-157

Junaidi, Amril, A., Kusuma, E. J., Ridwansyah, M., Hastuti, D. \& Aminah, S. (2019). Arahan Zonasi pada Pengembangan Agrowisata Berbasis Community Based Tourism Desa Renah Alai. Jurnal Inovasi, Teknologi dan Dharma Bagi Masyarakat, 1(1), 29-36.

Parmadi, P., Hastuti, D., Erfit, E., Nurjanah, R., \& Zeyava, F. (2019). Pengolahan Limbah Organik Rumah Tangga di Desa Renah Alai Kabupaten Merangin. Jurnal Inovasi, Teknologi Dan Dharma Bagi Masyarakat, 1(1), 43-50.

Septianti. E \& Fatah A. (2013). Diversifikasi Olahan Ubi jalar Menunjang Ketahanan Pangan. Prosiding Seminar Hasil Penelitian Tanaman Aneka Kacang dan Umbi, 683691

Zamzami, Z., \& Hastuti, D. (2019). Penyuluhan Potensi Danau Sipin pada Usaha Rumah Tangga Petani Keramba di Kota Jambi. Jurnal Inovasi, Teknologi Dan Dharma Bagi Masyarakat, 1(1), 56-61

Zulgani, Z., Emilia, E., Armandelis, A., \& Hardiani, H. (2019). Sosialisasi Konsep Agro Eco Tourism dalam Jajaran Aparatur Sipil Negara, Kepala Desa/Lurah, Lembaga Swadaya Masyarakat, Tokoh Masyarakat/Adat, Lembaga Pendidikan dan Kelompok Masyarakat di Kabupaten Merangin. Jurnal Inovasi, Teknologi Dan Dharma Bagi Masyarakat, 1(1), 62-66.

Zuraida,N. \& Supriati,Y. (2001).Usahatani Ubi Jalar sebagai Bahan Pangan Alternatif dan Diversifikasi Sumber Karbohidrat, Buletin AgroBio, 4(1):13-23. 